\title{
Globalization: Some Controversies and Its Humanization
}

\author{
Matiur Rahman ${ }^{1, ~ *}$ Prashanta K. Banerjee ${ }^{2}$ \\ ${ }^{1}$ Finance, McNeese State University, Lake Charles, LA \\ ${ }^{2}$ Finance and Banking, Bangladesh Institute of Bank Management, Dhaka, Bangladesh
}

Email address:

mrahman@mcneese.edu (M. Rahma), banerjee1167@gmail.com (P. K. Banerjee)

\section{To cite this article:}

Matiur Rahman, Prashanta K. Banerjee. Globalization: Some Controversies and Its Humanization. Journal of World Economic Research. Special Issue: The Globalization and Economic Structure Changes. Vol. 4, No. 5-1, 2015, pp. 20-26. doi: 10.11648/j.jwer.s.2015040501.13

\begin{abstract}
This paper studies the issue of interactive reinforcements among per capita real GDP, literacy rate and life expectancy invoking pooled OLS. Annual data from 2000 through 2013 are employed for selected twenty Asian countries. The results reveal strong interactions among the above three variables underscoring the importance of human capital and longer longevity of people in enhancing economic well-being. Polices towards improving them will put a human face on globalization.
\end{abstract}

Keywords: Globalization, Per Capita Real GDP, Literacy Rate, Life Expectancy, Pooled OLS

\section{Introduction}

Globalization has become a popular term used in a remarkable variety of contexts. In its broadest sense, the term encompasses all types of transnational economic and cultural transfers. Globalization is a multidimensional concept involving a wide variety of political, sociological, environmental and economic trends that are the concerns of worldwide academic and policy attention (Bond and O'Bryne, 2014). To economists, globalization, in general, is thought of as the increasing internationalization of production, distribution and marketing of goods and services (Palmer, 2002). Conventionally, globalization is perceived as a benevolent process linking rich and poor nations through unfettered flows of goods, services and capital fostering co-prosperity (Farrell, 2007; EuroStat, 2007).

Global trade and investment exert a profound impact on employment relations and work arrangements around the world. For the global workforce, economic globalization has no single meaning. The impacts can be both negative and positive differing by context, by industry and trade, and by employment status. Some find new jobs or new markets for their products while others have lost jobs or markets. Furthermore, many workers have seen their wages decline, their working conditions deteriorate, or their workloads increase (Furceri and Loungani, 2013).

The export-led growth strategy has rarely been associated with sustainable poverty reduction in the least developed countries during the 1990s and henceforth even though trade contributes a rising proportion of their GDP consequent upon gearing up of trade liberalization. Presumably, they gain less from trade than industrial countries partly because of falling commodity prices and specialization in low value-added products. Market access, though important, is not yet enough to enable them to reach an aspiring level of development. Growth can be immiserizing where positive growth idea leads to higher poverty and income inequality in the absence of equitable redistribution. There are some cross-country evidences to support this hypothesis (Son, 2004) calling for pro-poor growth strategies. Three distinct groups of people keep the debates on globalization alive and heated. The cheerleaders would like to see globalization rolling by defending the orthodoxy. The cynics highlight the concern that corporate and financial interests of developed countries dominate the global system. The critics acknowledge the benefits of globalization but worry about its costs. They usually tend to be economists and seem to feel uncomfortable because they lack the ideological conviction of the cheerleaders and the cynics. To them, a rising tide does not necessarily raise all boats. Factually, globalization raises yatches much more than row-boats.

Poor nations are urged to adopt macroeconomic prudence, deregulation, privatization and liberalization to engender linkages with the global economy (the so-called Washington Consensus). This prescription of standard macroeconomic restructuring and adjustment programs do not suit all countries because of structural, social and political asymmetries. In other words, all economies are not structurally identical. So, the prophecy of "One-Size-Fits-All" is not workable. Specifically, the push for an agenda of free capital movements 
may be detrimental to developing countries. Trauma of transition economies, tantalizing effects in Latin America despite decades of reforms and elsewhere support this view. The 1997 financial debacle of East Asia, the 2008-2009 global financial meltdowns, the economic meltdown of Argentina, the US corporate scandals and stock market crash, the decade-long deflation in Japan and current flirtation of the Euro-zone with deflation have raised more serious doubts about the benefits of financial globalization. As a result, skeptics are growing in numbers all over the world (Prasad et al., 2003, Bluedorn, 2013)

To a growing number of people, economic globalization has been a misplaced overemphasis without due regards for social and human developments. The primary focus of economic globalization has been on boosting material prosperity measured by the dubious growth in per capita real GDP to paint an improved macroeconomic picture. The macroeconomic data do not always necessarily reveal what truly happen at the microeconomic level. Additionally, globalization favors the formal economy with relatively little attention for the informal economy that constitutes a large segment of any developing economy. As a result, the wage-gap widens between formal and informal sectors of a developing economy (Fleming and Soborg, 2014).

The success of globalization should not be judged based only upon the macroeconomic performance indices. For a comprehensive assessment, the social and human development indices should also be considered in conjunction with the aforementioned since they interact with one another to shed light on both quantitative and qualitative aspects of well-being. To mitigate the problems of abject poverty, exorbitantly high unemployment, rising inter-country and intra-country income inequality and deteriorating living conditions in developing countries, a comprehensive and balanced approach calls for close academic and policy attention for shared prosperity. Surprisingly, till today nearly one-third of the population in developing countries live on less than $\$ 1.25$ a day. The world income distribution is being skewed more in favor of the top 20 percent of the income earners through preceding decades despite gathering momentum of globalization (Bowles, 2010).

Falk (1997), Khan (1996), and Sen (1997) contend that globalization will benefit more the powerful economic entities than weak nations. Arguably, globalization augments the importance of service industries and skilled labor, also reduces the importance of the primary commodities and unskilled labor to the detriment of poor nations. The revolutions in biotechnology, microelectronics and the like have eroded the importance of raw materials. Consequently, countries that were once considered wealthy being endowed with natural resources are no more in the list of rich countries. The progress in technology not only changed the structure of inputs but it also changed their significance. Modern industries use fewer natural resources. As a result, their importance has fallen out of the competitive equation. In modern economy, technology, knowledge and skills stand as the only source of comparative advantage (Thurow, 1996). Such a scenario puts developing countries, the main exporters of primary goods and unskilled labor, in a very disadvantageous position. Moreover, globalization forces developing countries to operate in accordance with the discipline of the global market, limiting the effectiveness of their national development policy. Bonvin (1997) points out: "The autonomy and effectiveness of national economic policy have decreased as a direct result of globalization of financial markets and financial deregulation." The growth in the global financial market and highly mobile private funds are weakening the ability of countries' central banks to manage exchange rates and design effective and sound macroeconomic policies. However, as Harris (1998) argues that there is still some scope for national policies, since global integration is far from perfect.

Economic development is human development. But outmigration of the best and the brightest from developing countries to the more advanced countries create a drain on the developing economy. Thus, any loss of human capital is a loss for economic development. This trend can be reversed by improving the living conditions in developing countries. This is possible only through expanding access to affordable public education and creation of job opportunities. Moreover, restrictions on international migration dampen the transnational free flows of knowledge and ideas to the detriment of global well-being. This can increase productivity, decrease costs to consumers, promote cultural interchange, increase profits (keeping employers from relocating to low-wage economies), establish close relationship between rich and poor nations, facilitates FDI and improves the lives of workers in less developed economies (Weinstein, 2002). To add further, student flows across economies serve as a useful channel of R\&D spillover (Park, 2004). Knowledge and technology diffusions help economic growth convergence.

Global modes of production and accumulation are allegedly linked to natural environmental degradation (e.g., extraction of natural resources, deforestation, $\mathrm{Co}_{2}$ emissions, other forms of pollution, exports of cancer-causing fertilizers to developing countries). Transnational corporations relocate more environmentally unfriendly production to countries with relatively less environmental controls- the developing economies (Waller-hunter and Jones, 2002).

The capitalist world-economy cannot find solutions for ecological degradation (Jorgenson and Kick, 2003; Cutter et al., 2009). This stirs controversies and heightens skepticisms about the vigor and the vitality of globalization. To make globalization pragmatic, more informed international policies and practices are needed to mitigate the deleterious effects of environmental pollution. Ignoring the principle of equity, the proponents of globalization are risking a loss in economic efficiency. This requires to take necessary corrective steps (Stiglitz, 2002) to minimize rising global discontents. The present fractured process of globalization is more likely to end up in regionalism or even national protectionism or rivalry leading to global disconnects (Khan, 2004).

The importance of interactions among economic, social and human developments is being recognized in the existing and the yet-evolving relevant literatures. Primarily, each of the 
aforementioned has been investigated mostly in isolation both theoretically and empirically, although they reinforce one another continually within an integrated system for overall well-being. Each concept is broadly defined and none of these factors have a comprehensive and precise measure available. As a result, their proxies are used in empirical studies. The most commonly used proxies in the empirical literature are real per capita GDP for economic development, life expectancy at birth for social development, and literacy rate or school enrollment or average number of years of schooling for human development (more precisely, human capital).

The growth in per capita real GDP is conditional on the initial level of human capital in addition to the initial level of per capita real GDP (Mankiw, Romer and Weil, 1992). Using the World Bank typology, countries are blocked into four, namely, "High Income", "Upper Middle Income", "Lower Middle Income", and "Low Income". Such classifications are used to study the convergence issue of per capita real GDP (Barro and Sala-i-Martin, 1992).

The principal focus of this paper is to explore the interactions among economic, social and human developments for 20 selected Asian countries since Asia alone has around 67 percent of the current world population (of nearly 7.5 billion). The remainder of the paper is designed as follows. Section II reviews the related literature. Section III outlines the empirical methodology. Section IV reports empirical results. Section V offers conclusions and policy implications.

\section{Review of the Related Literature}

Social indicators have been used informally for a long time in economics to assess the state of the nation and programs towards national objectives. Measuring people's quality of life emphasizes human well-being and particularly issues of equity, poverty and gender gap. Social development indicators are a major challenge for policies aiming to foster sustainable human development that involves improving the social, economic, cultural, political and environmental conditions of a nation to improve quality of human life without compromising the future of next generations (Medina, 1996).

The conceptualization of human development and the strategies to foster it have varied through history. During the 1960 s, the main concern was the economic growth having interest in the productive value of investment in training and education (Colcolough, 1993). The assessment of human development was principally concentrated in the value of human Capital (Schultz, 1961; Becker, 1964). In the 1970s, the international concern focused upon poverty alleviation and income redistribution (Colclough, 1993). International programs of healthcare and primary schooling targeted the poorest segments of the society. By the end of the 1970s, the focus shifted towards growth concerns and social developments as an interdisciplinary approach (Taylor and Jodine, 1983). The developmental approach, in general , replaced the efforts of human development of the 1970s with an encouragement for privatizations and commitment in support of basic educational and health goals. Meanwhile, the United Nations Development Program (UNDP) was emphasizing the need for placing people at the center of development because "people are the real wealth of nations". The UN policies since 1990 has been focusing on poverty alleviation by providing the basic services to the poor. Primary education, health care, family planning, and nutrition and self - employment programs seem receiving added attention.

Evidences from cross-country growth regressions suggest that better health yields sizable economic returns. To explain how health influences GDP per capita, healthy workers are more productive than workers who are otherwise comparable but for their health. One strand of supporting evidence comes from studies on individuals that link investments in health and nutrition of the young to adults (Bloom, et al., 2004). For good health, mitigation of pollution at early stage of industrialization is a necessity (Nigam, 2009).

Better health also raises per capita income through a number of other channels (Appendix- I). One way is by altering decisions about expenditures and savings over the life cycle. The idea of planning for retirement occurs only when mortality rates become low enough for retirement to be a realistic prospect. Rising longevity in developing countries has opened a new incentive for the current generation to save an incentive that can have dramatic effects on national saving rates. While this saving boom lasts for only one generation and is offset by the needs of the elderly once population aging occurs, it can substantially boost investment and economic growth rates while it lasts. Another channel is by encouraging foreign direct investment: investors shun environments where the labor force suffers a heavy disease burden. Yet another channel is through expanding access to quality education. Healthier children have higher rates of school attendance and improved cognitive development, and a longer life span can make investment in education more attractive.

The initial beneficiaries of health improvements are often the most vulnerable group: children. Lower infant mortality initially creates a "baby boom" cohort and often leads to a subsequent reduction in the birth rate as families choose to have fewer children in the new low-mortality regime. A baby-boom cohort is thus unique and affects the economy profoundly as it enters education, then finds jobs, saves for retirement, and, finally, leaves the labor market. The cohorts before and after a baby boom are much smaller.

If better health improves an economy's productive potential, one would expect good health to go hand in hand with higher steady-state output. However, there may be a lag such that economies adjust gradually to their steady-state output level over time. In this case, it is expected that countries with high levels of health but low levels of income experience relatively faster economic growth as their income adjusts. Evidences from cross-country growth regressions suggest the contribution is large. Indeed, the initial health of a population has been identified as one of the most robust and potent drivers of economic growth among such well-established influences as the initial level of income per capita (once countries reach their steady-state level of income, growth 
slows), geographic location, institutional environment, economic policy, initial level of education and investments in education. For example, Bloom, Canning and Sevilla (2004) found that one extra year of life expectancy raises steady-state GDP per capita by about 4 percent.

Bhargava, et al. (2001) found that better health matters more for wages in low-income countries than in high-income countries. Studies also show that better health matters more for countries with good economic policies, such as openness to trade and good governance. Bloom, Canning, and Malaney (2000) concluded that the East Asian growth miracle was actually no miracle at all, rather it represents compelling evidence for a process in which health improvements played a leading role in the context of generally favorable economic policies.

A sound measure of human development is not yet available since "Human Development Index -HDI" developed by the UNDP has significant conceptual limitations. HDI also misjudges the measurement of social development. A new social indicator "Literate Life Expectancy" as developed in Lutz (1995) is innovative, simple, and accounts for only two essential elements of social development: literacy and life expectancy. Education and healthcare are the leading sectors for social development. Basic education and health are simply measured by the number of people who are literate and by the number of years of personal survival, respectively.

Traditionally, nations strive to achieve a higher per capita real GDP and it is erroneously considered the single and most important element to measure their national prosperity. The use of per capita real GDP as an indicator of social development fails to capture the distribution of economic progress. This might produce a misleading picture of a country's social development, insofar as it does not reflect important elements of social prosperity such as education and health.

The accumulation of human capital has gained a central role in the recent growth literature. Lucas (1988) has postulated that human capital is an input in the production process like any other; its accumulation implies capital deepening with an associated period of accelerated growth towards a new steady state growth path of output. Moreover, human capital is necessary for the discovery of new technologies and thus its stock is permanently related to the growth rate of output (Nelson and Phelps, 1966; Romer, 1990; Aghion and Howitt, 1992). Bassanini and Scarpetta (2001) find a significant impact of human capital accumulation on per capita output growth. Although there is strong theoretical support for a key role of human capital in the growth process, evolving empirical evidences are not quite clear. Card (1999) and Psacharopoulos (1994) find that one additional year of schooling is associated with between 5 and 15 percent higher earning across countries. Also, Jorgenson et al., (1987) and Young $(1994,1995)$ provide some additional support to a significant growth impact of human capital accumulation. In contrast, Benhabib and Spiegel (1994), Islam (1995), Pritchett (1996), and Topel (1999) find that the evolution of human capital over time is not statistically related to output growth
(Varghese, 2011). In contrast, Freire-Seren (2002) confirms that human capital has a positive and significant effect on the growth of income. However, the findings of empirical studies are dependent upon methodologies employed, sample periods used, countries studied and the types of data used.

\section{Empirical Methodology}

The estimating static models employed in levels in this study are as follows:

$$
\begin{gathered}
y_{i t}=\alpha+\phi x_{i t}+\psi z_{i t}+u_{i t} \\
x_{i t}=\alpha^{\prime}+\beta^{\prime y_{i t}}+\psi^{\prime z_{i t}}+u_{i t}^{\prime} \\
z_{i t}=\alpha^{\prime \prime}+\beta^{\prime \prime} y_{i t}+\phi^{\prime \prime} x_{i t}+u_{i t}^{\prime \prime}
\end{gathered}
$$

where, $y=\log$ of per capita real GDP, $x=\log$ of adult literacy rate for age 15 and above, $z=\log$ of life expectancy at birth, $u$ $=$ random disturbance term, $\mathrm{i}=$ individual countries and $\mathrm{t}=$ time subscript. The logarithmic transformation of each variable is intended to compress excess kurtosis and to induce variance homogeneity. Annual data are employed in this paper. The sample period spans from 2000 through 2013 for 20 selected Asian countries. Adult literacy rate is considered as a proxy for human capital using data on school enrollment or average years of schooling across countries. Likewise, life expectancy at birth is considered instead of the literate life expectancy due to data inadequacy. Only 20 Asian countries are selected in this paper for which complete data are obtained from the annual volumes of UNDP's Human Development Reports (2000-2013). The countries included in the sample are Bangladesh, China, Djibouti, Fiji, Indonesia, India, Iran, Jordan, Kazakhstan, Cambodia, Lao PDR, Malaysia, Pakistan, Philippines, Sri Lanka, Syria, Thailand, Tajikistan, Vietnam, and Yemen. To overcome the problem of small sample bias, a panel data set is created by combining time series and cross-sectional data in this paper. The above interactive models are estimated by pooled OLS (Beck and Katz, 1995). Models in levels using this technique do not require assumption of strict exogeneity.

\section{Empirical Result}

The estimates of models (1),(2) and (3) for contemporaneous interactions are reported as follows:

Table 1. Model (1), (y as Dependent Variable)

\begin{tabular}{lllll}
\hline Variable & Coefficient & Std. Error & t-Statistic & Prob. \\
\hline Common Intercept & -9.673717 & 0.201421 & -48.02732 & 0.0000 \\
$\mathrm{x}$ & 1.017725 & 0.013704 & 74.26309 & 0.0000 \\
$\mathrm{z}$ & 2.894370 & 0.039301 & 73.64618 & 0.0000 \\
\hline $\bar{R}^{2}=0.353621, \mathrm{~F}=20.4286$ & & &
\end{tabular}

As observed in Table1, both adult literacy rate (x) and life expectancy $(\mathrm{z})$ exert significantly positive influences on per capita real GDP (y). The coefficients are statistically highly significant at 1 percent level of significance, as confirmed by the associated $t$-values and $p$-values. The estimates are reliable 
since the problems of heteroscedasticity and autocorrelation are automatically corrected by the computer program. $\bar{R}^{2}$ indicates that 35.36 percent of the per capita real GDP in the selected Asian countries is explained by adult literacy rate and life expectancy. The F-statistic is also quite high indicating the overall significance of model (1).

Likewise, the estimates of model (2) are reported as follows:

Table 2. Model (2), (x as Dependent Variable)

\begin{tabular}{lllll}
\hline Variable & Coefficient & Std. Error & t-Statistic & Prob. \\
\hline Common Intercept & 1.287759 & 0.176531 & 7.294804 & 0.0000 \\
y & 0.127751 & 0.009509 & 13.43443 & 0.0000 \\
z & 0.526691 & 0.042227 & 12.47292 & 0.0000 \\
\hline
\end{tabular}

$\bar{R}^{2}=0.299030, \mathrm{~F}=16.1010$

Table 2 depicts that both per capita real GDP and life expectancy have statistically significant and positive effects on adult literacy rate at 1 percent level of significance, as confirmed by the associated t-values and $p$-values. The estimates are reliable and efficient for the same reasoning, as stated above. The numerical value of $\bar{R}^{2}$ shows that the aforementioned causal factors can explain about 30 percent of the change in the adult literacy rate in the selected Asian countries. The F-statistic at 16.1010 is again quite high to reveal the overall significance of model (2).

Finally, the estimates of model (3) are provided as follows:

Table 3. Model (3), ( $\mathrm{z}$ as Dependent Variable)

\begin{tabular}{lllll}
\hline Variable & Coefficient & Std. Error & t-Statistic & Prob. \\
\hline Common & 3.319638 & 0.023274 & 142.6359 & 0.0000 \\
Intercept & & & & \\
y & 0.049080 & 0.000637 & 77.03014 & 0.0000 \\
x & 0.120076 & 0.005136 & 23.37758 & 0.0000 \\
\hline
\end{tabular}

$\bar{R}^{2}=0.34006, \mathrm{~F}=19.2796$,
Table 3 reveals that per capita real GDP and adult literacy rate in selected Asian countries have positive and statistically significant causal effects on life expectancy. They are confirmed by the associated t-values and p-values. Again, the estimates are reliable in the same vein. $\bar{R}^{2}$ shows that 34 percent of life expectancy is explained by per capita real GDP and adult literacy rate. Again the F-statistic is quite significant.

\section{Conclusions and Policy Implications}

To recapitulate, per capita real GDP, adult literacy rate, and life expectancy in Asian countries significantly and positively reinforce one another. Thus, the goal of economic prosperity cannot be accomplished by paying inadequate attention to human and social developments. They all should be considered together as an interactive and integrating system. As a result, the policymakers should design and implement balanced policies for enhancing economic well-being in conjunction with human capital formation and adequate access to affordable healthcare. An overemphasis on economic progress alone without due regards for education, environment and healthcare is lopsided, to say the least. Inadequate or poor investment in them cannot ensure long-term sustainable development (Slaus and Jacobs, 2013; Lempart and Nguyen, 2011).

In closing, globalization is an enticing conceptual construct but it is plagued with many practical problems. To mitigate rising anti-globalization sentiments particularly in developing countries, the shifting paradigm needs to be humanized by developed countries without any further delay through income redistribution, greater market access, investing in education, developing infrastructure, technology sharing, etc. Otherwise, the overpromises will eventually invite its own perils in the long-run.

\section{Appendix-I}

Health's links to GDP: Poor health reduces GDP per capita by reducing both labor productivity and the relative size of the labor force.

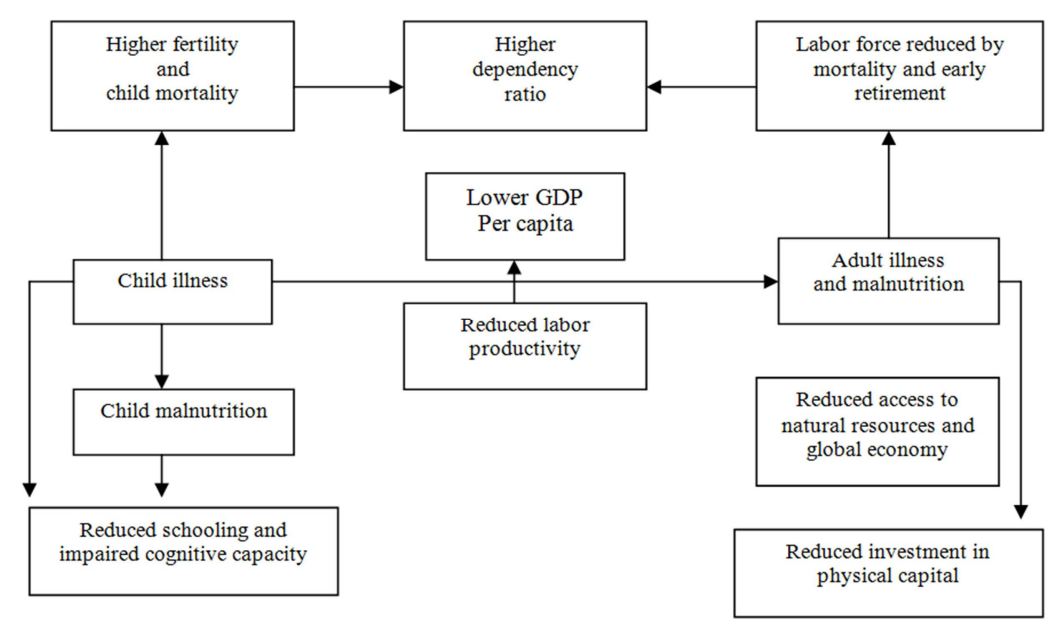

Source: Ruger, Jennifer Prach, Dean T. Jamison, and David E. Bloom, 2001, “ Health and the Economy.” Page 619 in International Public Health, edited by Michael H. Merson, Robert E. Black, and Anne J. Mills ( Sudbury, Massachusetts: Jones and Barlett). 


\section{References}

[1] Aghion, P. and P. Howitt (1998). "Endogenous Growth Theory", The MIT Press, Cambridge, Mass.

[2] Barro, R.J. and X. Sala-i-Martin (1992). " Convergence", Journal of Political Economy, 100, 223-251.

[3] Bassanini, A. and S. Scarpetta. (2001). "Does human capital matter for growth in OECD countries? Evidence from pooled mean-group estimates", Working Paper No. 282, Economics Department, OECD.

[4] Becker, G.S. (1964). "Human Capital", New York: Columbia University Press.

[5] Beck, N. and J.N. Katz, (1995). "What to do (and not to do) with time-series cross-section data", American Political Science review, 89, 634-47.

[6] Benhabib, J. and M. Spiegel (1994), " The role of human capital in economic development: evidence from aggregate cross-country data", Journal of Monetary Economics, 43, 143-174.

[7] Bhargava, Alok., Dean T. Jamison, Lawrence J. Lau, and Christopher J.L. Murray. (2001). "Modeling the effects of health on economic growth", Journal of Health Economics, 20, 423-440.

[8] Bluedorn, M.J.C., R., Duttagupta, Guajardo, J., and P. Tapalova, (2013). "Capital flows are fickle: Anytime, anywhere", Working Paper WP/13/183, International Monetary Fund, Washington, DC.

[9] Bloom. David E., David Canning, and Pia Malaney. (2002). "Demographic change and economic growth in Asia", Supplement to Population and Development Review, 26, 257-290.

[10] Bloom, David E., David Canning, and J. Sevilla. (2004). "The Effect of Health on Economic Growth: A Production Function Approach", World Development 32, 1-13.

[11] Bloom, David E., David Canning, and Dean T. Jamison. (2004). "Health, wealth and welfare", Finance and Development, 41, $10-15$.

[12] Bonds, Christopher and O'Bryne, Darren, J. (2014). "Challenges and conceptions of globalization. An investigation into models of global change and their relationship with business practice", Cross Cultural Management, 21, 23-38.

[13] Bovin, J. ( 1997). "Globalization and linkages: Challenges for development policy", Development, 40(2): 29-42.

[14] Bowles, P. (2010). “Globalization's problematic for labor: Three paradigms”, Global Labor Journal, 1, 12-31.

[15] Card, D. (1999). "The causal effects of schooling on earnings", in O. Ashenfelter and D. Card (eds.) Handbook of Labor Economics, Amsterdam, North Holland.

[16] Colclough, C. (1993). "Human Development: towards a more integrated framework for planning in the 1990s", Discussion Paper 323. Brighton, England: Institute of Development Studies.

[17] Cutter, S., Emrich, C., Webb, J., and Morath D. (2009). "Social vulnerability to climate variability hazards: A review of the literature", Final Report to Oxfam America, University of South Carolina, Department of Geography, Hazards and Vulnerability Research Institute, Columbia, SC.

[18] EuroStat (2007). "Euro indicator, selected readings, focus on measuring globalization", Luxembourg: European Commission.

[19] Falk. R. (1997). "Resisting globalization-from-above through globalization-from-below", New Political Economy, 2, 17-24.

[20] Farrell, R.R. (2007). "The future of globalization", The Real Truth, $\quad$ Magazine: http://www.realtruth.org/articles/07223-001-globalization.html

[21] Fleming, D. and H. Soborg (2014). "The debate on globalization and international revitalization of labor: A critical review", Nordic Journal of Working Life Studies, 4, 53-68.

[22] Freire -Seren, M. J. (2002). "On the relationship between human capital accumulation and economic growth", Applied Economics Letters, 9, 805-808.

[23] Furceri, D., and Loungani, P. (2013). "Who let the gini out?", Finance and Development, 50(4), 25-27.

[24] Harris, Laurence. (1998). "The dynamics of globalization: Eight skeptical theses", Paper presented at the UNU/AERC Conference, Tokyo, August 3-4, 1998.

[25] Islam, N. ( 1995). "Growth empirics: A panel data approach", Quarterly Journal of Economics, 110, 1127-1170.

[26] Jorgenson, Andrew K. and Edward L. Kick (2003). "Globalization and the environment", Journal of World Systems Research IX, pp.195-203.

[27] Jorgenson, D.W., F.M. Gollop, and, B.M. Fraumeni (1987), "Productivity and U.S. economic growth", Cambridge ,MA. Harvard Univ. Press.

[28] Khan, Haider A. (2004). "Globalization : Challenges and opportunities", Southwest Review of International Business Research, 15, 276-291.

[29] Khan, Haider A. (1996). "Beyond distributive justice in the McWorld", Global Justice, Spring /Summer, 30-40.

[30] Lucas, R. E. (1988). "On the mechanics of economic development", Journal of Monetary Economics, 22, 3-42.

[31] Lutz, W. 1995. "Literate life expectancy", International Institute for Applied Systems Analysis, POPNET ,26 (Winter), 1-5. Laxenburg, Austria

[32] Mankiw, G.N., D. Romer, and D.N., Well, (1992). "A contribution to the empirics of economic growth", Quarterly Journal of Economics, 107, 407-37.

[33] Medina, S. (1996). "Implementing a new indicator of social development in Mexico: literate life expectancy (LLE)", International Institute for Applied Systems Analysis, Laxenburg, Austria WP-96-103.

[34] Nelson, R. and E. Phelps (1966). "Investment in humans, technological diffusion and economic growth", American Economic Review, 56, 69-75. 
[35] Nigam, M. (2009). "Impact of globalization", http://monikanigam.articlesbase.com/science-articles/impact-o f-globalization-1095770.html

[36] Palmer, T.G. (2002). "Globalization is great!", Washington: Cato's Letter.

[37] Park, Jungsoo. (2004). "International student flows and R\&D spillover”, Economics Letters, 82, 315-320.

[38] Prasad, E.S., K., Rogoff,, Shang-Jin, Wei, and Ayan M. Kose (2003). "Effects of financial globalization on developing countries: Some empirical evidence", IMF, Occasional Paper 220.

[39] Pritchett, L. (1997). "Where has all the education gone?", Policy Research Working Paper No. 1581, The World Bank, Washington, D.C.

[40] Psacharopoulos, G. (1994). "Returns to investment in education: A global update", World Development, 22, 1325-1343.

[41] Romer, P.M. (1990). "Endogenous technological change", Journal of Political Economy, 98, 71-102.

[42] Schultz, T.W. (1961). "Investment in human capital", The American Economic Review, 51, 1-17.

[43] Sen , G. (1997). "Globalization, justice and equity: A gender perspective", Development, 40, 21-26.

[44] Son, Hyun Hwa. ( 2004). "A note on pro-poor growth", Economics Letters, 82, 407-314.

[45] Steger, M.B. (2009). "Globalization: A very short introduction", Hampshire: Oxford University Press.
[46] Stiglitz, J. 2002. "Globalization and Its Discontents", New York : Norton.

[47] Taylor, C. L. and D. A. Jodine. (1983). "World handbook of political and social indicators", Third Edition. New Haven: Yale University Press.

[48] Topel, R. (1999). "Labor markets and economic growth", in O. Ashenfelter and D. Card (eds.), Handbook of Labor Economics, Amsterdam, North Holland.

[49] Thurow, L. (1996). "The future of capitalism: How Today's Economic Forces Shape Tomorrow's World”, Penguin Books: New York.

[50] United Nations Development Program (UNDP). (2000-2013). Human Development Reports 2000-2013. New York: Oxford University Press.

[51] Waller, Christian E and Adam Hersh. (2004). "The long and short of it : Global liberalization and the incomes of the Poor", Journal of Post Keynesian Economics, 26, 471-503.

[52] Weinstein, Eric. (2002). "Migration for the Benefit of all: Towards a New Paradigm for economic immigration", International Labor Review, 141, 225-252.

[53] Varghese, N. (2011). "Globalization and cross-border education: Challenges for the development of higher education in commonwealth countries", Kuala Lumpur: International Institute for Educational Planning (IIEP).

[54] Young, A. (1994). "Lessons from the East Asia NIC's: a contrarian view”, European Economic Review, 38, 964-973.

[55] Young, M.E. (1977). "Social indicators: A bibliography with annotations", Springfield, VA: NTIS. 